\title{
Save media!
}

\section{Benni Setiawan}

Universitas Negeri Yogyakarta, Indonesia

Email:bennisetiawan@uny.ac.id

Print mass media face a big problem. One of them is the decline in subscribers, and the print mass media also loses advertisers. The migration of readers from print to online is not only during a pandemic but has occurred since the last few decades. However, when the Covid-19 pandemic hit, the print media became more difficult. The media reduces production costs by laying off employees. The press also reduced the number of pages to stay afloat in difficult times.

Print media also have to deal with the advertising market system getting away from it. Advertisers trust influencers more than mainstream mass media. Influencers with large numbers of followers beat the mass media advertising market. Products/services rely more on their advertisements to influencers to quickly and precisely target audiences.

In addition, the routine of media work during the pandemic also causes saturation. This limitation of space means journalists can only cover from home. This information mining model can reduce the value of news as a guide for the community.

The routine of media work which tends to be monotonous, is often faced with the changing reality of society. People prefer to get fast news rather than indepth. The public can also access reports without waiting for tomorrow because of the ease of information facilities.

Print media is increasingly challenging to develop amid declining public purchasing power for media. Not many people are willing to set aside some of their funds to "buy" quality information. One of the sources of the life of the print media is the selling price of newspaper products. 
People need to set aside funds to buy media products for media life. Buying media is a fundamental step to saving media from bankruptcy. Encouraging the purchase value of this media also needs to get a response from the media by presenting better, engaging, and creative news. Of course, all that needs to pay attention to ethics and journalistic rules.

When people turn on the media, then as a source of information, the press continues to live in the life of nationhood and civility. People's purchasing power is a healthy choice during consumption flows. Buy media at Rp. 60,000Rp. 100,000 per month is certainly cheaper than the consumption of cigarettes, fast food, or the cost of hanging out at a coffee shop. With that critical and constructive life is maintained, media workers can still live in the onslaught of change.

In addition, the public needs to stop the distribution of the paper that has been purchased. Of course, it's easy to find in various WhatsApp groups every morning someone shares media paper. His intentions may be good but spreading the report can reduce people's enthusiasm to buy media. It is enough that the subscription is enjoyed by the customer and perhaps the immediate family.

In the end, the print mass media, in particular, need to be saved with genuine attention and steps from the public. Keeping the press from extinction is a form of moral responsibility to revive a reliable source of information. More than that, saving the media means maintaining sanity and civility. 